\title{
Anti-inflammatory and Antinociceptive Activity of Ouabain in Mice
}

\author{
Danielle Ingrid Bezerra de Vasconcelos, ${ }^{1,2}$ Jacqueline Alves Leite, ${ }^{1}$ Luciana Teles Carneiro, ${ }^{1}$ \\ Márcia Regina Piuvezam, ${ }^{1,2}$ Maria Raquel Vitorino de Lima, ${ }^{1}$ Liana Clébia Lima de Morais, ${ }^{1}$ \\ Vivian Mary Rumjanek, ${ }^{3}$ and Sandra Rodrigues-Mascarenhas ${ }^{1,2}$
}

\author{
${ }^{1}$ Laboratório de Tecnologia Farmacêutica, Departamento de Fisiologia e Patologia, Centro de Ciências da Saúde, \\ Universidade Federal da Paraíba, João Pessoa 58059-900, Brazil \\ ${ }^{2}$ Departamento de Biologia Molecular, Centro de Ciências Exatas e da Natureza, Universidade Federal da Paraíba, \\ João Pessoa 58059-900, Brazil \\ ${ }^{3}$ Instituto de Bioquímica Médica, Centro de Ciências da Saúde, Universidade Federal do Rio de Janeiro, \\ Rio de Janeiro 21941-902, Brazil
}

Correspondence should be addressed to Sandra Rodrigues-Mascarenhas, sandramascarenhas@ltf.ufpb.br

Received 23 November 2010; Revised 17 February 2011; Accepted 26 March 2011

Academic Editor: Muzamil Ahmad

Copyright ( 92011 Danielle Ingrid Bezerra de Vasconcelos et al. This is an open access article distributed under the Creative Commons Attribution License, which permits unrestricted use, distribution, and reproduction in any medium, provided the original work is properly cited.

\begin{abstract}
Ouabain, an inhibitor of the $\mathrm{Na}^{+} / \mathrm{K}^{+}$-ATPase pump, was identified as an endogenous substance of human plasma. Ouabain has been studied for its ability to interfere with various regulatory mechanisms. Despite the studies portraying the ability of ouabain to modulate the immune response, little is known about the effect of this substance on the inflammatory process. The aim of this work was to study the effects triggered by ouabain on inflammation and nociceptive models. Ouabain produced a reduction in the mouse paw edema induced by carrageenan, compound $48 / 80$ and zymosan. This anti-inflammatory potential might be related to the inhibition of prostaglandin E2, bradykinin, and mast-cell degranulation but not to histamine. Ouabain also modulated the inflammation induced by concanavalin A by inhibiting cell migration. Besides that, ouabain presented antinociceptive activity. Taken these data together, this work demonstrated, for the first time, that ouabain presented in vivo analgesic and antiinflammatory effects.
\end{abstract}

\section{Introduction}

Ouabain, one of the oldest drugs used for treatment of cardiac insufficiency, is classically known as a specific inhibitor of the plasma membrane $\mathrm{Na}^{+} / \mathrm{K}^{+}$-ATPase [1]. Originally isolated from plants, it was demonstrated that mammals naturally produce an endogenous analogue of ouabain, a hormone synthesized in the adrenal glands, hypothalamus, and pituitary and found circulating in the plasma [2-5]. Accumulating evidence suggests that circulating levels of endogenous ouabain are modulated by stress conditions. Elevated plasma levels of ouabain were found in hypertensive patients and after physical exercise in different species [6-8].
The steroid ouabain is capable of modulating many aspects of the immune system, being considered as an immunomodulatory molecule [9]. Ouabain, in vitro, inhibits mitogen-induced thymocyte and lymphocyte proliferation $[10,11]$, inhibits the generation of lymphokine-activated killer (LAK) activity induced by IL-2 [12], increases intracellular calcium levels [13], increases CD69 expression [14] and acts both in vitro [15] and in vivo [16] synergistically with corticoids. In vitro, ouabain increases glucocorticoidinduced plasma membrane depolarization in lymphoid cells [9]. Besides that, ouabain downregulates mCD14 expression on monocytes, which is related to inflammatory response against several pathogens [17] and induces IL- $1 \beta$ production on human mononuclear cells [18]. 
Additionally, this molecule is also capable of inducing the activation of various signal transduction cascades that are independent of changes in intracellular $\mathrm{Na}^{+}$and $\mathrm{K}^{+}$concentrations, involving the Ras/Raf/mitogen-activated protein kinase (MAPK) cascade, transactivation of epidermal growth factor receptor (EGFR), and protein kinase C [17, 19-23]. In murine thymocytes, ouabain decreased the levels of phosphorylated MAPK p38 and nuclear factor of activated T-cells (NFATc1) induced by the mitogen concanavalin A [24].

Besides the effects described in the immune system, little is known about the role of ouabain in inflammatory processes. During inflammation, a complex program of intracellular signal transduction and transcription events, driven by multiple proinflammatory mediators and cytokines, is activated. The acute inflammation is characterized by exudation of protein-rich fluid, edema, vasodilatation, and cell migration, primarily neutrophils, into the site of injury [25]. It was reported that ouabain suppressed the production of the pro-inflammatory cytokines IL- 6 and TNF- $\alpha$ stimulated with LPS both in vitro and in vivo [26]. In addition, cardiac glycoside drugs inhibits TNF- $\alpha / \mathrm{NF}-\kappa \mathrm{B}$ signaling pathway, which is a central common regulator for the process of inflammation [27].

The aim of the present study was to investigate the role of ouabain in acute peripheral inflammation induced by intraplantar and intraperitoneal injection of different phlogistic agents and in algesic processes.

\section{Material and Methods}

2.1. Animals. Female swiss albino mice ( 2 months old) were housed in a temperature-controlled room and received water and food ad libitum. After manipulation, euthanasia was employed by cervical dislocation. The study was performed according to the Guidelines on Ethical Standards for Investigation of Experimental Pain in Animals [28], after approval of protocol no. 0407/08 by the Institutional Ethics Committee of Laboratório de Tecnologia Farmacêutica.

2.2. Treatment with Ouabain. In all experiments, $0.56 \mathrm{mg} / \mathrm{kg}$ ouabain [16] or phosphate buffered saline (PBS) was given intraperitoneally (i.p.) for three consecutive days. A doseresponse curve was also performed using $0.10 \mathrm{mg} / \mathrm{kg}$ and $0.31 \mathrm{mg} / \mathrm{kg}$ ouabain, and $0.56 \mathrm{mg} / \mathrm{kg}$ ouabain was given i.p. for one and two consecutive days.

2.3. Inflammatory Paw Edema. To induce inflammation, mice received subcutaneous injections in the plantar surface [29] of carrageenan (2.5\%), compound 48/80 (2 $\mu \mathrm{g} / \mathrm{paw})$, zymosan $(1 \%)$, histamine $(100 \mu \mathrm{g} / \mathrm{paw})$, prostaglandin E2 $(5 \mu \mathrm{g} / \mathrm{paw})$, and bradykinin $(6 \mathrm{nmol} / \mathrm{paw})$ in $20 \mu \mathrm{L}$ of phosphate buffered saline (PBS) in the right (ipsilateral) hindpaw and $20 \mu \mathrm{L}$ of PBS in the left (contralateral) hindpaw. Captopril $(5 \mathrm{mg} / \mathrm{kg}$ ) was used $1 \mathrm{~h}$ prior to bradykinin challenge in order to prevent the action of kininases [30]. Ouabain last treatment was injected i.p. one hour before intraplantar injections of phlogistic agents. All the reagents were obtained from Sigma. Hindpaw edema was measured with a digital micrometer (Instrutemp 070393611) [31] and is expressed as the difference of thickness ( $\mathrm{mm})$ between the stimulated and the saline-injected paw.

Dexamethasone $(0.5 \mathrm{mg} / \mathrm{kg})$, indomethacin $(10 \mathrm{mg} / \mathrm{Kg})$ and salbutamol $(10 \mathrm{mg} / \mathrm{kg})$ were used as antiinflammatory controls and injected i.p. or subcutaneous (s.c.) one hour before intraplantar injections.

2.4. Peritoneal Inflammation Model. Mice were injected intraperitoneally with 60 ug Concanavalin A diluted in sterile saline solution to a final injection volume of $0.1 \mathrm{~mL}$ one hour after the last ouabain administration. After $24 \mathrm{~h}$, animals were sacrificed and peritoneal lavage was performed with $10 \mathrm{~mL}$ of sterile PBS [32-34]. The fluid was removed for total and differential cell counts and results were reported as cell number $/ \mathrm{mL}$ of peritoneal wash. Differentiation of leukocyte subpopulations in peritoneal lavage fluids was performed on cytospin preparations stained with WrightGiemsa solution (Sigma, St. Louis, Mo, USA). For each slide a minimum of 100 cells was counted microscopically under 1000 magnification.

2.5. Acetic Acid Induced Writhing Test. Acetic acid administration causes irritation resulting in painful contortions followed by extension of hind limbs [35]. The animals were injected i.p. with $0.1 \mathrm{~mL} / 10 \mathrm{~g}$ of $0.8 \%$ (v/v solution) acetic acid one hour after the last treatment with ouabain $(0.56 \mathrm{mg} / \mathrm{kg})$. Morphine $(6 \mathrm{mg} / \mathrm{Kg})$ (i.p.) was used for analgesia. Ten minutes after the administration of acetic acid, mice were placed in separate boxes and the number of abdominal writhes was counted for 10 minutes. The antinociceptive activity was expressed as the reduction in the number of abdominal writhes when compared to control animals.

2.6. Hot Plate. Animals were placed on a hot plate maintained at $52 \pm 1^{\circ} \mathrm{C}$. The time elapsed between placing the animal on the hot plate, and the animal either licking its fore or hind paws or jumping on the surface was considered the response latency [36]. Mice with baseline latencies of more than $15 \mathrm{~s}$ were excluded from the study. Response latency testing was measured 30, 60 and 120 minutes after the last treatment with Ouabain $(0.56 \mathrm{mg} / \mathrm{kg})$, saline or the positive control, morphine $(10 \mathrm{mg} / \mathrm{Kg})$. The cutoff time for the hotplate test latency was set at $30 \mathrm{~s}$ to avoid tissue injury. All animals were brought to the test room at least $1 \mathrm{~h}$ prior to the experiments and were not tested more than once.

2.7. Possible Involvement of Opioid Receptors. In order to investigate the involvement of the opioidergic system in ouabain-induced antinociception, separate groups of mice were pretreated with nonselective opioid receptor antagonist, naloxone $(5 \mathrm{mg} / \mathrm{kg}$, s.c.), which was injected $15 \mathrm{~min}$ before i.p. administration of ouabain $(0.56 \mathrm{mg} / \mathrm{kg})$ and morphine (10 mg/kg, i.p.), and tested using the hot plate test [37].

2.8. Elevated Plus maze. The apparatus is comprised of two open arms $(35 \times 5 \mathrm{~cm})$ and two closed arms $(30 \times 5 \times 15 \mathrm{~cm})$ 


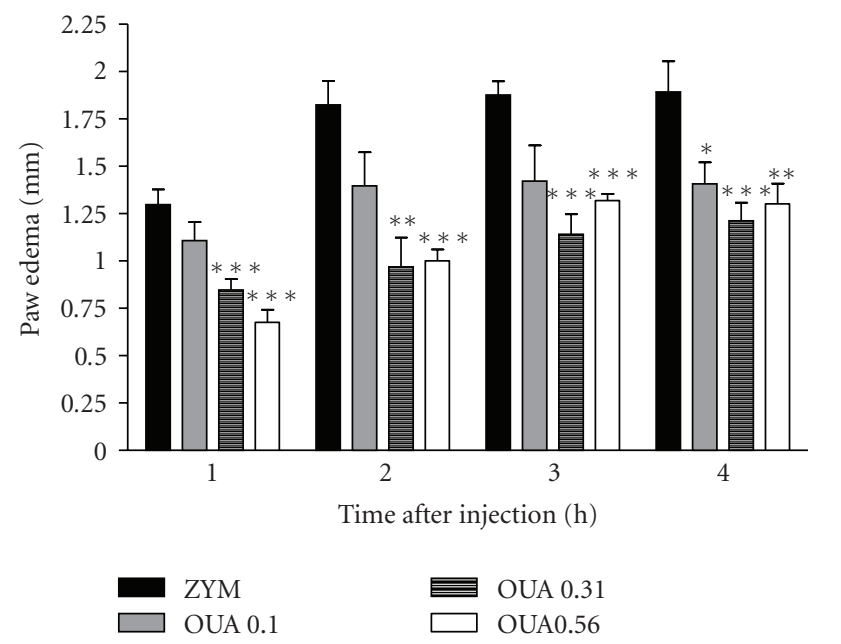

(a)

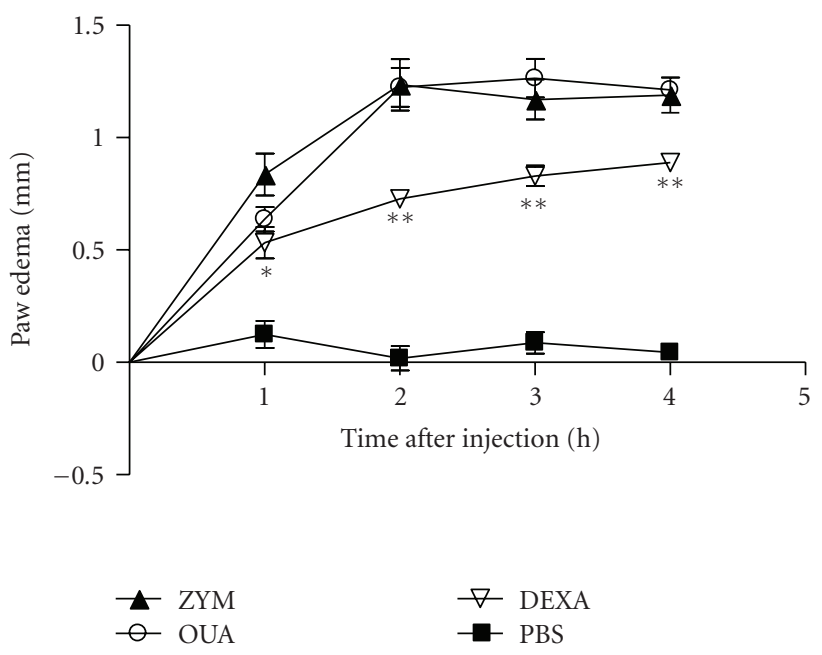

(b)

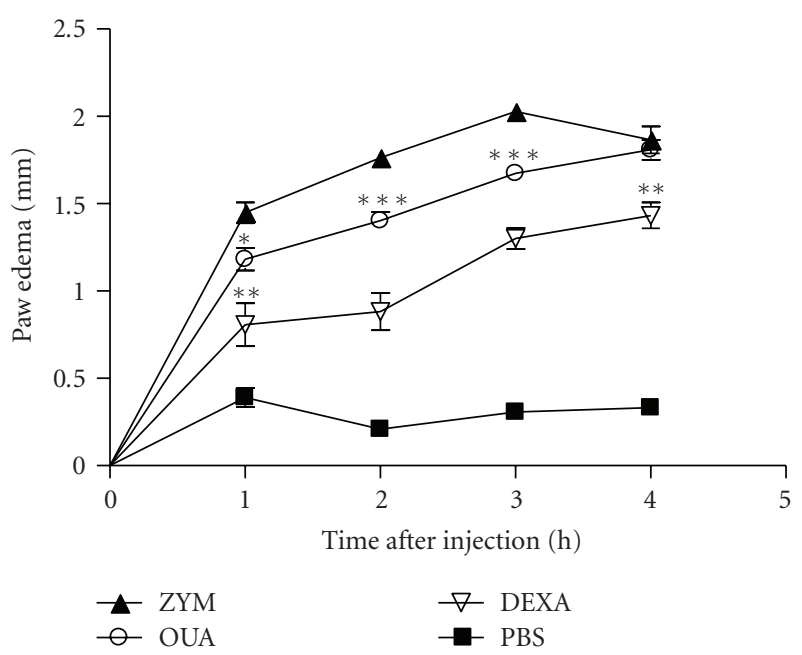

(c)

FIgURE 1: Ouabain dose-response curve and administration for 1 and 2 consecutive days. Mice were pretreated with $0.10 \mathrm{mg} / \mathrm{kg}, 0.31 \mathrm{mg} / \mathrm{kg}$ and $0.56 \mathrm{mg} / \mathrm{kg}$ ouabain for 3 consecutive days (a) or with $0.56 \mathrm{mg} / \mathrm{kg}$ ouabain for 1 (b) and 2 consecutive days (c); one hour after the last ouabain treatment, mice received intraplantar injections of zymosan in $20 \mu \mathrm{L}$ phosphate buffered saline (PBS) in the right hindpaw and $20 \mu \mathrm{L}$ of PBS in the left hindpaw. Each point represents the mean of eight animals. Dexametasone (DEXA, $0.5 \mathrm{mg} / \mathrm{kg}$ ) was used as antiinflammatory control and injected i.p. one hour before intraplantar challenge. Asterisks denote the significance levels compared with ZYM group. Data were expressed as mean \pm S.E.M. and analyzed by software Graphpad Prism using Student's $t$-test followed by unpaired test. ${ }^{*} P<.05$, ${ }^{* *} P<.01$, and ${ }^{* * *} P<.001$.

that extended from a common central platform $(5 \times 5 \mathrm{~cm})$. The entire maze was elevated to a height of $30 \mathrm{~cm}$ above floor level [38]. One hour after ouabain administration, mice were placed in the central region of the plus-maze apparatus. Diazepan $(0.5 \mathrm{mg} / \mathrm{Kg})$ was administred $30 \mathrm{~min}$ before the test and used as positive control.

2.9. Statistical Analysis. All data were expressed as mean \pm S.E.M. and analyzed by software Graphpad Prism using Student's $t$-test followed by unpaired test or ANOVA followed Dunnett's or Mann Whitney test, and the results were considered significant if $P<.05$.

\section{Results}

3.1. Effect of Ouabain on Carrageenan, Zymosan, and 48/80Induced Mice Paw Edema. The paw edema induced by carrageenan and zymosan involves various mediators such as histamine, bradykinin, and prostaglandins $[39,40]$. Although $0.10 \mathrm{mg} / \mathrm{kg}$ ouabain was without effect, $0.31 \mathrm{mg} / \mathrm{kg}$ and $0.56 \mathrm{mg} / \mathrm{kg}$ ouabain prevented zymosan edema formation (Figure 1(a)). On the other hand, ouabain was not able to inhibit zymosan-induced paw inflammation when administered only one day prior experiment (Figure 1(b)). Furthermore, when ouabain was given for two days prior experiment, it did not interfere in the edema present $4 \mathrm{~h}$ 


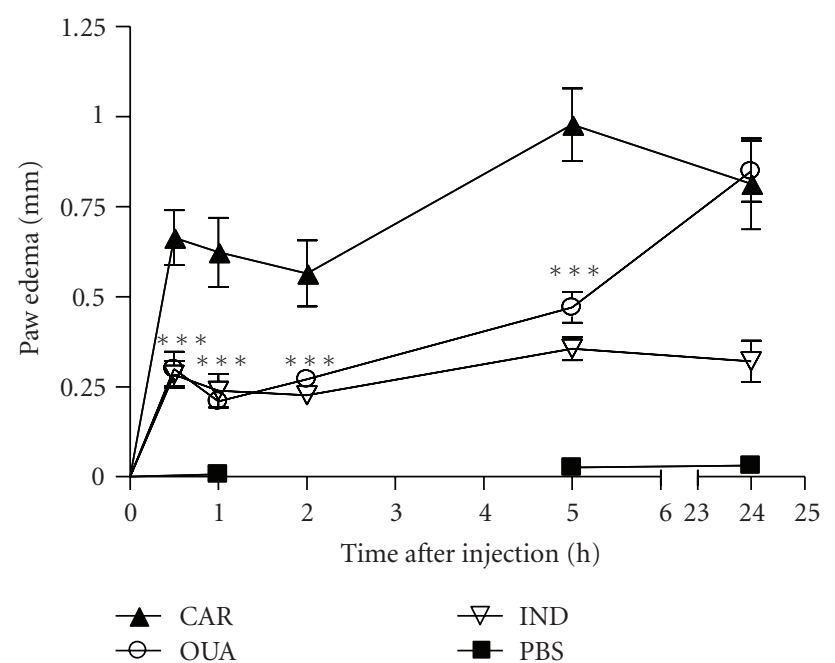

(a)

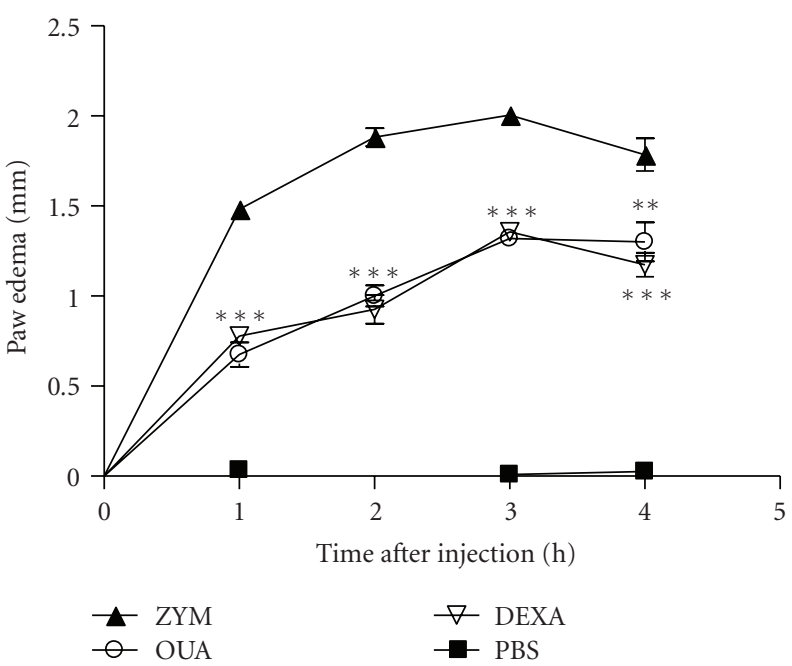

(b)

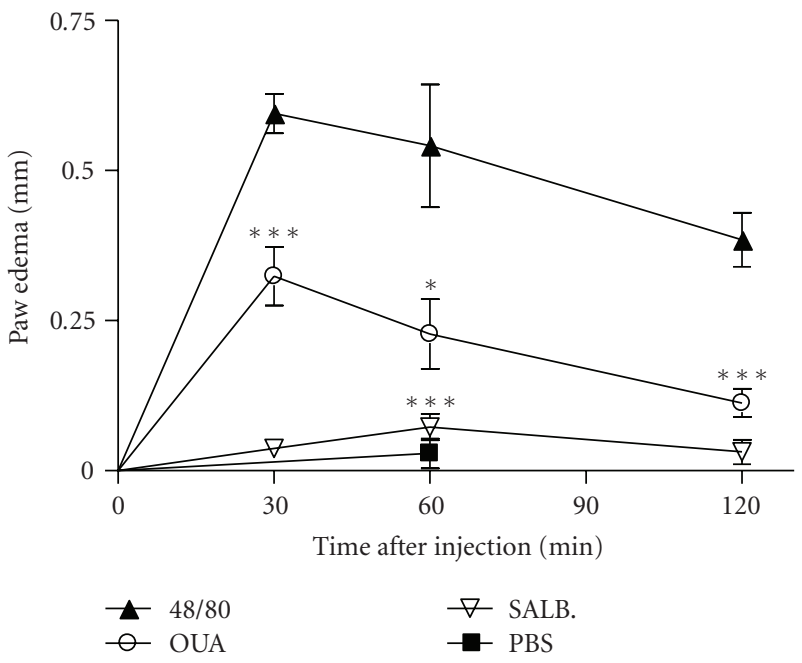

(c)

FIGURE 2: Effect of the pretreatment with Ouabain (OUA, $0.56 \mathrm{mg} / \mathrm{kg}$ ) administered intraperitoneally on paw edema triggered by carragenan (CAR), zymosan (ZYM), and compound 48/80 in mice. Mice received intraplantar injections of carrageenan (2.5\%, (a)), zymosan (1\%, (b)), or compound 48/80 (2 $\mu \mathrm{g} / \mathrm{paw}$, (c)) in $20 \mu \mathrm{L}$ phosphate buffered saline (PBS) in the right hindpaw and $20 \mu \mathrm{L}$ of PBS in the left hindpaw. Each point represents the mean of eight animals. Indomethacin (IND, $10 \mathrm{mg} / \mathrm{Kg}$ ), dexametasone (DEXA, $0.5 \mathrm{mg} / \mathrm{Kg}$ ), and salbutamol (SALB, $10 \mathrm{mg} / \mathrm{kg}$ ) were used as antiinflammatory controls and injected i.p. one hour before intraplantar challenge. Asterisks denote the significance levels compared with CAR, ZYM, or compound 48/80 group. Data were expressed as mean \pm S.E.M. and analyzed by software Graphpad Prism using Student's $t$-test followed by unpaired test $* P<.05$, ${ }^{* *} P<.01$, and ${ }^{* * *} P<.001$.

after zymosan (Figure 1(c)). Ouabain $0.56 \mathrm{mg} / \mathrm{kg}$ injected for three consecutive days, prevented zymosan edema formation at the 1 st $(54.4 \%), 2$ nd $(47.1 \%)$, 3rd (34.7\%), and 4 th $h$ (26.9\%) after treatment, as well as did $0.5 \mathrm{mg} / \mathrm{kg}$ dexamethasone (Figure 2(b)). Similarly to what was observed with zymosan, carrageenan-induced paw edema was also significantly reduced in a time-dependent manner by the treatment of $0.56 \mathrm{mg} / \mathrm{Kg}$ ouabain at $30 \mathrm{~min}(54.9 \%)$, 1st $(66.4 \%)$, 2nd $(51.0 \%)$, and $5 \mathrm{~h}(51.9 \%)$ after carrageenan treatment (Figure 2(a)). On the other hand, ouabain did not interfere in the edema present $24 \mathrm{~h}$ after carrageenan injection. A significant antiinflammatory effect of indomethacin at the dose of $10 \mathrm{mg} / \mathrm{Kg}$ was observed at all times studied. Paw edema induced by compound $48 / 80$ was short lasted, with a peak $30 \mathrm{~min}$ after injection. Ouabain significantly inhibited the edema, but to a lesser extent than salbutamol, at 30 (69.1\%), 60 (79.7\%), and $120 \mathrm{~min}(49.7 \%)$ after compound $48 / 80$ injection (Figure 2(c)).

3.2. Effect of Ouabain on Paw Edema Triggered by Different Inflammatory Mediators. The results in Figure 3(a) indicate that ouabain was incapable to inhibit the edema induced by histamine at any of the times studied. On the other hand, the administration of ouabain produced a significant reduction in the mouse paw edema induced by prostaglandin E2 and bradykinin (Figures 3(b) and 3(c)). A significant antiedema 


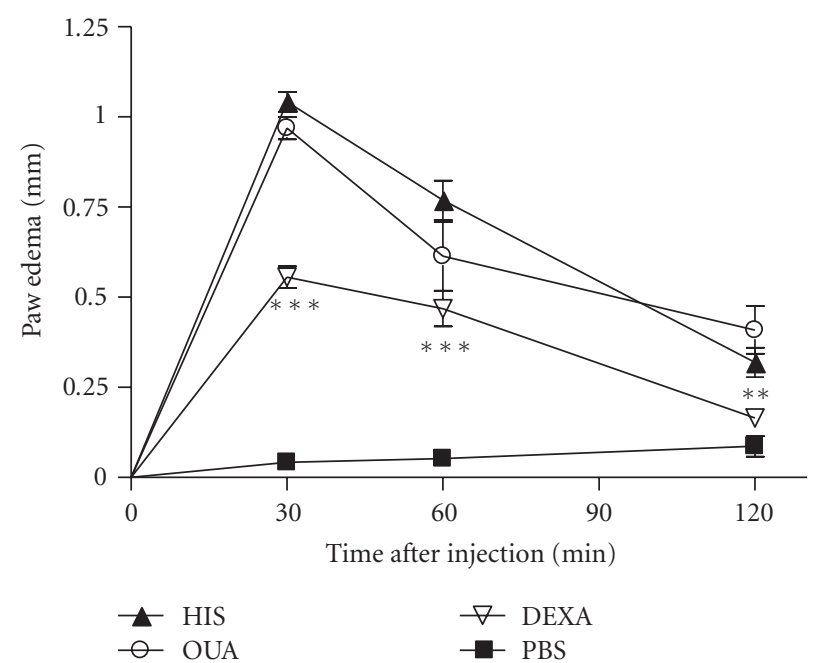

(a)

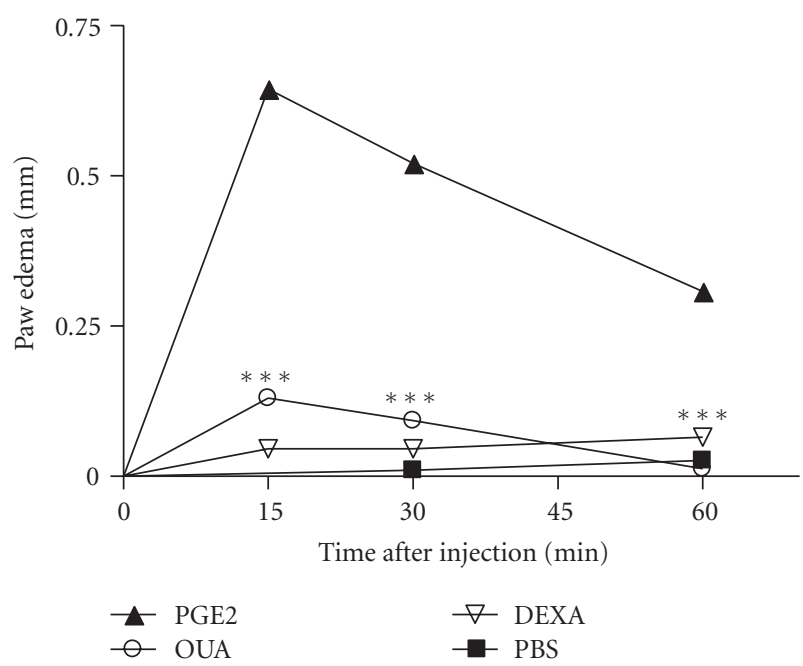

(b)

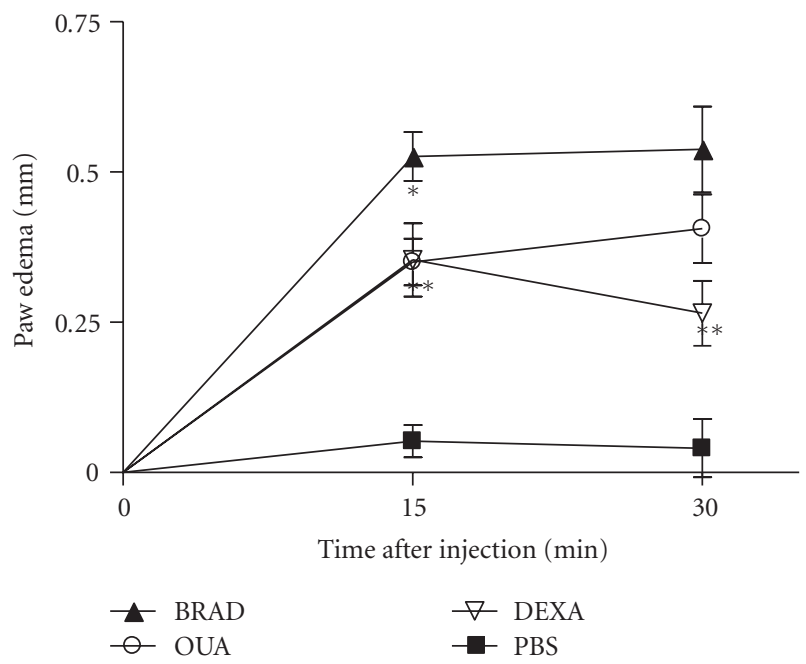

(c)

FIGURE 3: Effect of the pretreatment with Ouabain (OUA, $0.56 \mathrm{mg} / \mathrm{kg}$ ) administered intraperitoneally on paw edema triggered by histamine (HIS), prostaglandin E2 (PGE2) and bradykinin (BRAD). Mice received intraplantar injections of histamine (100 $\mu \mathrm{g} / \mathrm{paw}$, (a)), prostaglandin E2 $(5 \mu \mathrm{g} /$ paw, (b) ) or bradykinin $(6 \mathrm{nmol} / \mathrm{paw},(\mathrm{c}))$ in $20 \mu \mathrm{L}$ of phosphate buffered saline (PBS) in the right hindpaw and $20 \mu \mathrm{L}$ of PBS in the left hindpaw. Each point represents the mean of eight animals. Dexametasone $(0.5 \mathrm{mg} / \mathrm{kg})$ was used as antiinflammatory control and injected i.p. one hour before intraplantar challenge. Data were expressed as mean \pm S.E.M. and analyzed by software Graphpad Prism using Student's $t$-test followed by unpaired test ${ }^{*} P<.05,{ }^{* *} P<.01$, and ${ }^{* * *} P<.001$.

effect of ouabain was observed at 15 (79.8\%), 30 (82.1\%) and $60 \mathrm{~min}(96.0 \%)$ after prostaglandin E2 challenge and at 15 $(34.0 \%)$ but not at $30 \mathrm{~min}$ after bradykinin challenge.

\subsection{Effect of Ouabain Treatment on the Cellular Influx into the} Peritoneal Cavity. Peritoneal inflammation was induced and the number of cells recruited into the peritoneal cavity was measured as an indication of the degree of inflammation. As shown in Figure 4(a), the administration of ouabain alone had no effect on the number of resident peritoneal cells in unchallenged mice. However, after induction of inflammation, treatment with ouabain led to a $70 \%-80 \%$ reduction in the total cell numbers in the peritoneal cavity after $24 \mathrm{~h}$, as a reflex of the inhibition of polymorphonuclear leukocytes (Figure 4(b)). These data are consistent with an attenuated inflammatory response observed.

3.4. Effect of Ouabain on Acetic Acid-Induced Writhing Response. The results of acetic acid-induced writhing responses in mice, which indicate ouabain's analgesic activity, were presented in Figure 5(a). It was demonstrated that ouabain caused a significant inhibition $(45 \%)$ on the writhing responses induced by acetic acid when compared to the control group, as well as did the analgesic drug, $6 \mathrm{mg} / \mathrm{kg}$ morphine $(78 \%)$.

3.5. Effect of Ouabain on the Hot Plate Test and Involvement of Opioid Receptors. The results of the hot plate test revealed 


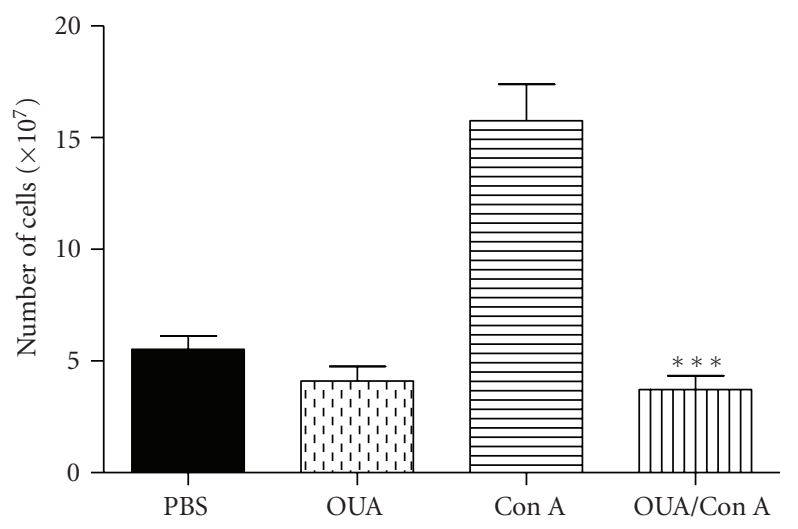

(a)

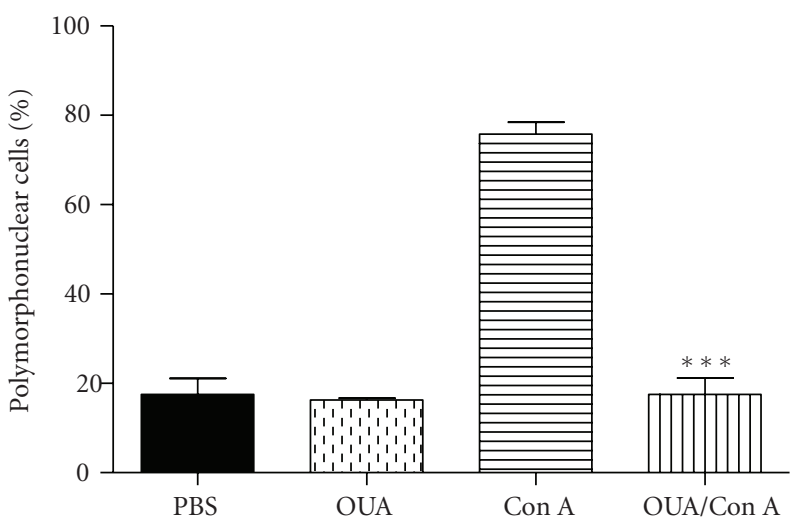

(b)

FIGURE 4: Effect of the pretreatment with Ouabain (OUA, $0.56 \mathrm{mg} / \mathrm{kg}$ ) administered intraperitoneally on peritoneal inflammation triggered by Concanavalin A (ConA, $60 \mu \mathrm{g} / 300 \mu \mathrm{L})$ on total (a) and differential cell counts (b). Each bar represents the mean of nine animals. Asterisks denote the significance levels compared with Con-A values. Data were expressed as mean \pm S.E.M. and analyzed by software Graphpad Prism using Student's $t$-test followed by unpaired test ${ }^{* *} P<.01$ and ${ }^{* * *} P<.001$.

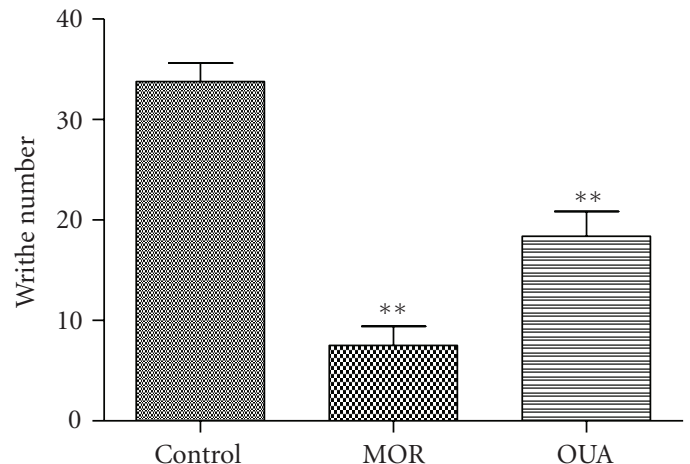

(a)

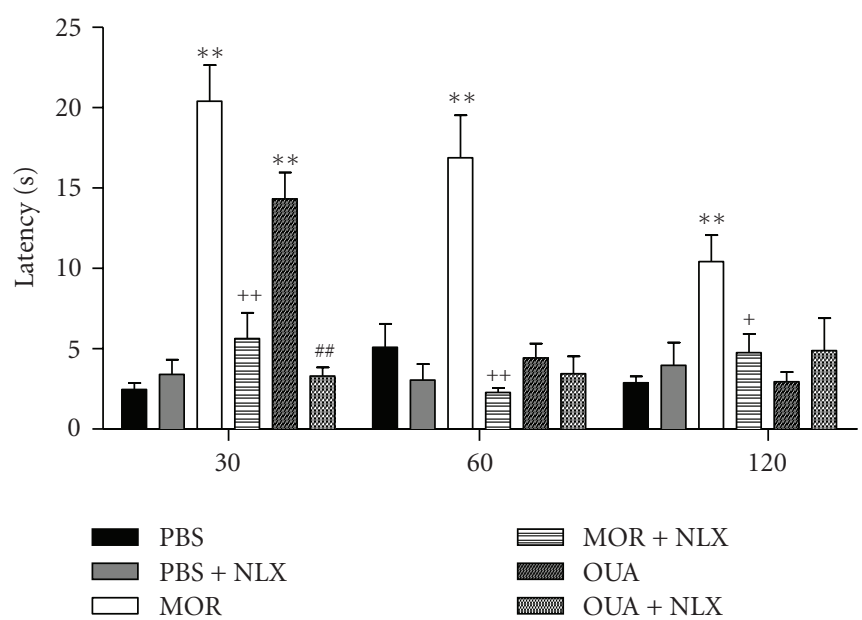

(b)

FIGURE 5: Effect of the pretreatment with Ouabain (OUA, $0.56 \mathrm{mg} / \mathrm{kg}$ ) administered intraperitoneally on acetic acid-induced writhing and hot plate test in mice. Each bar represents the mean of six or ten animals. Morphine (MOR, $10 \mathrm{mg} / \mathrm{kg}$ ) administered intraperitoneally was used for analgesia. Naloxone (NLX, $5 \mathrm{mg} / \mathrm{kg}$ ), an opioid antagonist, was used to test the involvement of opioid receptors. Asterisks denote the significance level compared with control values; \# compared with the Ouabain group and + compared with the morphine group. Data were expressed as mean \pm S.E.M. and analyzed by software Graphpad Prism using (ANOVA) followed Dunnett's test. ${ }^{*} P<.05,{ }^{* *} P<.01$, and $* * * P<.001$.

that the latency time was increased $(74 \%)$ when animals were tested $30 \mathrm{~min}$ after the last injection of ouabain. Pretreatment of mice with naloxone inhibited the antinociceptive effect triggered by ouabain (around 77\%). On the other hand, ouabain was not capable to interfere in the latency observed after 60 or $120 \mathrm{~min}$. The analgesic drug, morphine $(10 \mathrm{mg} / \mathrm{kg})$ modulated the pain, increased the latency time (more than $70 \%$ ), and it was significantly reversed by naloxone (70\%), (Figure 5(b)).

3.6. Effect of Ouabain on Elevated Plus-Maze Test. The results of the elevated plus maze test revealed that ouabain did not interfere in the numbers of entries in open arms but increased the time spent (Figures 6(a) and 6(b)). Additionally, the number of visits was not modified, and the time spent in closed arms was decreased by ouabain (Figures 6(c) and $6(\mathrm{~d})$ ). Ouabain did not interfere in total number of entries (Figure $6(\mathrm{e}))$. The positive control $(0.5 \mathrm{mg} / \mathrm{Kg}$ diazepan), increased the number total of entries as well the number of entries and the time spent in open arms and decreased the time spent in closed arms.

\section{Discussion}

In agreement with the immunosuppressive effects that have been previously observed, in the present work, ouabain 


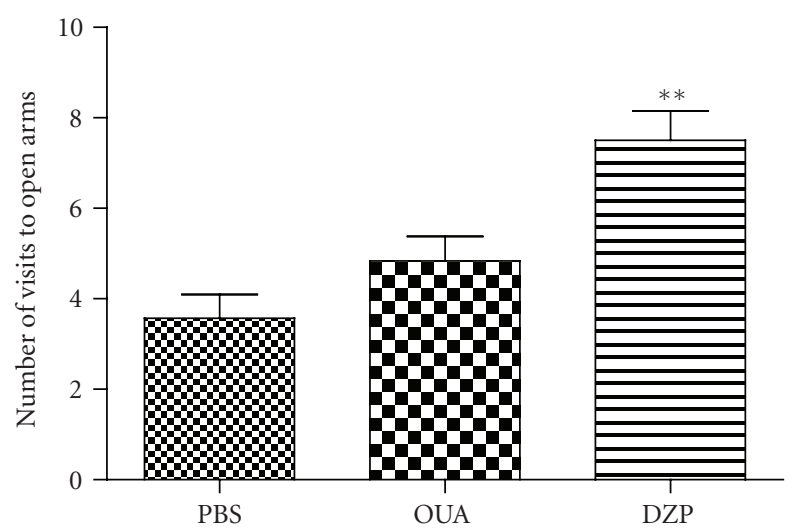

(a)

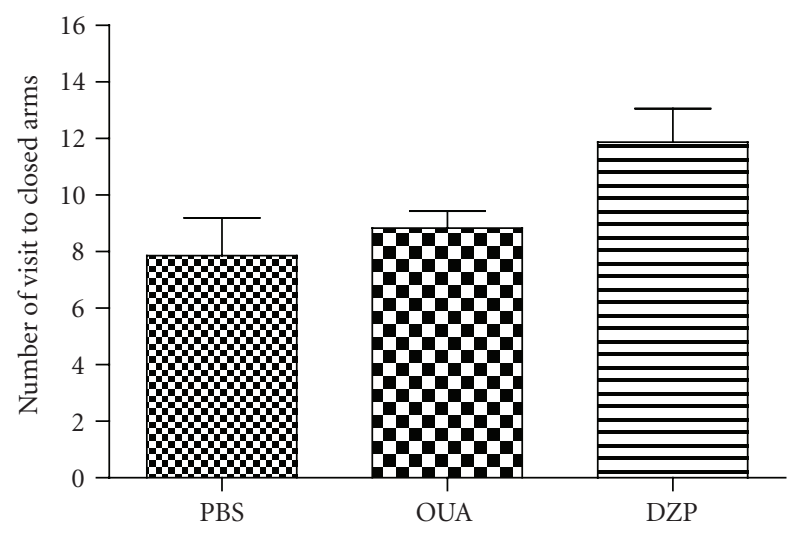

(c)

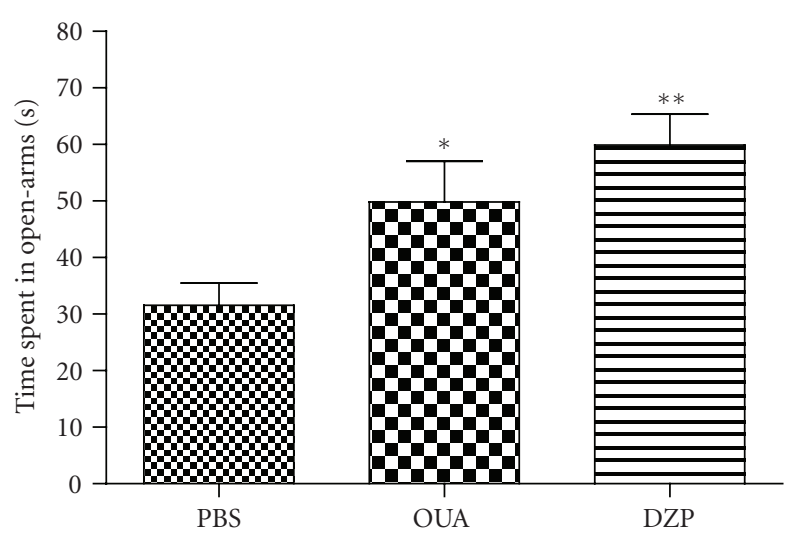

(b)

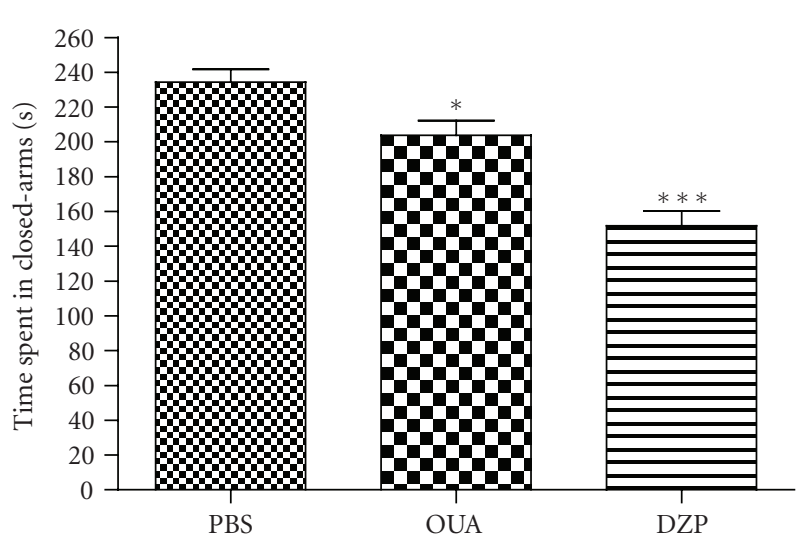

(d)

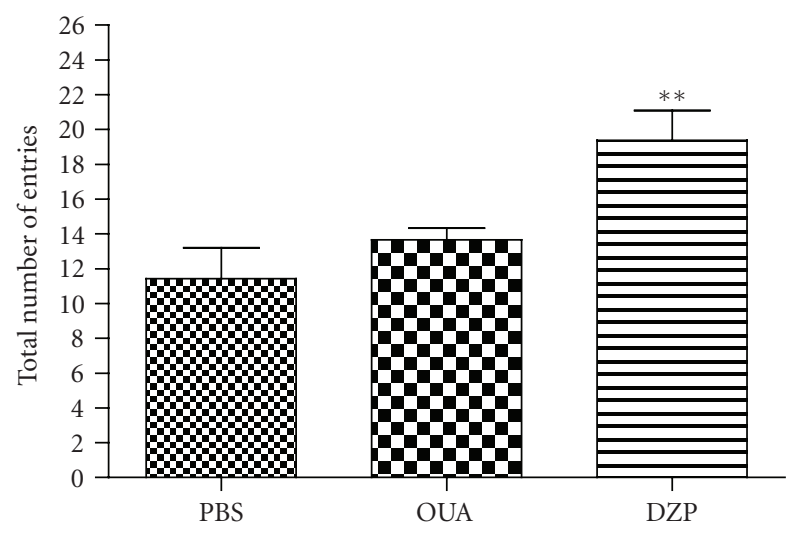

(e)

FIGURE 6: Effect of the pretreatment with Ouabain (OUA $0.56 \mathrm{mg} / \mathrm{kg}$ ) administered intraperitoneally on elevated plus-maze test in mice. (a) Number of visit to open-arms; (b) Time spent in open-arms; (c) Number of visit to closed-arms; (d) Time spent in closed arms; (e) Total numbers entries. Each bar represents the mean of seven or eight animals. Diazepan (DZP $0.5 \mathrm{mg} / \mathrm{Kg}$ ) was used as positive control. Data were expressed as mean \pm S.E.M. and analyzed by software Graphpad Prism using ANOVA followed Mann Whitney test or Student's $t$-test followed by unpaired test: ${ }^{*} P<.05,{ }^{* *} P<.01$, and ${ }^{* * *} P<.001$.

inhibited inflammation and nociception. To study the role of ouabain in the inflammatory process, initially we used the carrageenan and zymosan-induced paw edema. These models induce inflammatory responses, including edema formation, neutrophil infiltration, and the development of hyperalgesia [41].
Ouabain administered for three consecutive days was able to inhibit zymosan edema formation at all periods studied. On the other hand, ouabain was not able to inhibit zymosan-induced paw inflammation when administered only one day prior experiment. Furthermore, when ouabain was given for two days prior experiment, it did not interfere in 
the edema present $4 \mathrm{~h}$ after zymosan. Despite the fact that ouabain was effective at the $0.31 \mathrm{mg} / \mathrm{kg}$ concentration, the dose of $0.56 \mathrm{mg} / \mathrm{kg}$ was chosen because, using a different model, in a previous in vivo work, this concentration was effective [16]. The intraplantar administration of zymosan activates of the complement system [42] promotes increased expression of COX-2 and prostaglandin production, mainly of type E2, and increases the production of nitric oxide [39]. A controversy exists regarding the role played by ouabain on mast cell degranulation. Stimulatory and inhibitory effects were reported $[43,44]$. Some data have also demonstrated that ouabain had no effect on mast cell degranulation [45]. In this work, the edema induced by mast cell degranulation using compound $48 / 80$ was also inhibited.

In agreement with the results using zymosan, ouabain administered for three consecutive days was also able to inhibit carrageenan induced edema formation. Henriques and coworkers [46] showed that carrageenan injection into the mouse paw induces a biphasic edema that develops in the first $6 \mathrm{~h}$, followed by a second phase, which starts at $24 \mathrm{~h}$. The early phase is mainly mediated by histamine, serotonin, and by an increasing synthesis of prostaglandins such as prostaglandin E2. Recent studies have shown that carrageenan also induces peripheral release of nitric oxide (NO) sustained by TNF- $\alpha$, IFN-y, and IL- 1 . These cytokines have been shown to induce iNOS in a variety of cells [47]. The late phase is mainly sustained by prostaglandin release and NO [48]. In the present work, we found that ouabain inhibits the inflammation after $30 \mathrm{~min}, 1,2$, and $6 \mathrm{~h}$ but not after $24 \mathrm{~h}$ of carrageenan challenge. The antiinflammatory effect observed in the first phases could be related to the suppression of the pro-inflammatory cytokines IL- 6 and TNF- $\alpha$ [26] and by the blockade of the TNF- $\alpha / \mathrm{NF}-\kappa \mathrm{B}$ signaling pathway [27].

Taking this information into account, the effect of ouabain triggered by different inflammatory mediators related to carrageenan, zymosan, and compound 48/80-induced mouse paw inflammation was carried out. The present results demonstrate that ouabain produced a significant reduction in the mouse paw edema induced by prostaglandin E2 and bradykinin (at 15 minutes) but did not interfere in the edema induced by histamine. These findings suggest that the antiinflammatory effect of ouabain might be related to the inhibition of prostaglandin E2, bradykinin, and mast-cell degranulation but not to histamine.

Another feature of acute inflammation is cell migration, primarily neutrophils, into the site of injury. The inhibitory effect of ouabain on neutrophil migration was confirmed through peritoneal inflammation induced by concanavalinA. This mitogen possesses chemotactic activity for neutrophils [49] and ouabain produced a clear inhibition in the influx of polymorphonuclear cells to the peritoneal cavity. Together with the previous data, this result clearly demonstrates that ouabain has an antiinflammatory effect.

Prostaglandins are potent sensitizing agents able to modulate multiple sites of nociceptive pathways [50]. Prostaglandin E2 acts synergistically with bradykinin in the induction of pain. These substances are among the most important mediators of the inflammatory hyperalgesia [51-53]. Our results demonstrated that ouabain produced a significant reduction in the mouse paw edema induced by prostaglandin E2 and bradikynin. These data prompted us to evaluate the role of Ouabain in the nociception.

The acetic acid-induced abdominal writhing is a sensitive method to evaluate peripherally acting analgesics. In this model, opioid mechanisms and released arachidonic acid via cyclooxygenase and prostaglandin biosynthesis play a role in the nociceptive mechanism [54-56]. In the present work, it was demonstrated that ouabain and morphine, caused a significant inhibition, $45 \%$ and $78 \%$, respectively, on the writhing responses induced by acetic acid when compared to the control group. This peripheral analgesic potential might be related to the inhibition of PGE2 and bradykinin, as we have also found that ouabain reduced the edema formation induced by these mediators, suggesting that ouabain antinociceptive effect can be associated with an antiinflammatory action.

To better evaluate the role of ouabain in pain, we used the thermal model for nociception, the hot-plate test, which is specific central antinociceptive test [57-59]. Ouabain was found to have antinociceptive activity in the hot-plate test, increasing the latency time (74\%) when tested $30 \mathrm{~min}$ but not 60 nor $120 \mathrm{~min}$ after the last injection of ouabain. Animals were also pretreated with naloxone, an opioid antagonist that opposes the effects of opioid agonists such as morphine [37]. The results demonstrated that naloxone was capable to inhibit ouabain effect, indicating that at least in part, the antinociceptive effect of ouabain is also related to activation of opioid receptors. Using different models, it was also reported by other groups that ouabain exhibited antinociceptive effects $[60,61]$.

In an attempt to discard the possibility that the effect observed was due to a sedative effect on the animal behavior and not an analgesic effect, further experiments were performed, and mice were exposed to the elevated plus-maze test $[38,62-64]$. This test is based on the natural fear of open and elevated spaces, and, as a consequence, rats and mice tend to avoid the open arms and stay on the enclosed arms $[65,66]$. It was reported that an increase in the proportion of time spent in the open arms and in the proportion of entries into the open arms indicates anxiety reduction [38]. On the other hand, total number of arm entries is an indicator of motor activity [62-64]. Our data demonstrated that ouabain did not interfere in the mice anxiety behavior or in the motor function, when compared to the control group. As expected, the positive control $(0.5 \mathrm{mg} / \mathrm{Kg}$ diazepan) leads to anxiety reduction demonstrated by an increase in the number of visits and time spent in the open arms and by an increase in the total number entries. These results suggest that the analgesic effect of ouabain is not related to sedative effect or to motor function.

\section{Conclusion}

For the first time, the present work demonstrated, in vivo, the antiinflammatory and analgesic potential of ouabain which might be related to prostaglandin E2 and bradykinin as well as to opioid mechanisms. 


\section{Acknowledgments}

This work was supported by Fapesq (Fundação de Apoio à Pesquisa do Estado da Paraíba), CNPq (Conselho Nacional de Desenvolvimento Científico e Tecnológico), and FAPERJ (Fundação de Amparo à Pesquisa do Estado do Rio de Janeiro). The authors would like to acknowledge Airlla Laana de Medeiros Cavalcanti, Jéssica de Sá Barreto Callou Peixoto, Josenilson Feitosa de Lima, and Juliana da Silva Brandi Oliveira for helping in some experiments.

\section{References}

[1] G. Scheiner-Bobis and W. Schoner, "A fresh facet for ouabain action," Nature Medicine, vol. 7, no. 12, pp. 1288-1289, 2001.

[2] J. M. Hamlyn, M. P. Blaustein, S. Bova et al., "Identification and characterization of a ouabain-like compound from human plasma," Proceedings of the National Academy of Sciences of the United States of America, vol. 88, no. 14, pp. 6259-6263, 1991.

[3] M. Ferrandi, P. Manunta, S. Balzan, J. M. Hamlyn, G. Bianchi, and P. Ferrari, "Ouabain-like factor quantification in mammalian tissues and plasma: comparison of two independent assays," Hypertension, vol. 30, no. 4, pp. 886-896, 1997.

[4] J. Laredo, B. P. Hamilton, and J. M. Hamlyn, "Ouabain is secreted by bovine adrenocortical cells," Endocrinology, vol. 135, no. 2, pp. 794-797, 1994.

[5] W. Schoner, "Ouabain, a new steroid hormone of adrenal gland and hypothalamus," Experimental and Clinical Endocrinology \& Diabetes, vol. 108, no. 7, pp. 449-454, 2000.

[6] A. Goto, K. Yamada, H. Nagoshi, Y. Terano, and M. Omata, "Stress-induced elevation of ouabainlike compound in rat plasma and adrenal," Hypertension, vol. 26, no. 6, part 2, pp. 1173-1176, 1995.

[7] N. Bauer, J. Müller-Ehmsen, U. Krämer et al., "Ouabain-like compound changes rapidly on physical exercise in humans and dogs: effects of $\beta$-blockade and angiotensin-converting enzyme inhibition," Hypertension, vol. 45, no. 5, pp. 10241028, 2005.

[8] M. P. Blaustein, J. Zhang, L. Chen et al., "The pump, the exchanger, and endogenous ouabain: signaling mechanisms that link salt retention to hypertension," Hypertension, vol. 53, no. 2, pp. 291-298, 2009.

[9] S. Rodrigues-Mascarenhas, A. D. S. de Oliveira, N. D. Amoedo, O. R. Affonso-Mitidieri, F. D. Rumjanek, and V. M. Rumjanek, "Modulation of the immune system by ouabain," Annals of the New York Academy of Sciences, vol. 1153, pp. 153-163, 2009.

[10] M. Szamel, S. Schneider, and K. Resch, "Functional interrelationship between $\left(\mathrm{Na}^{+}+\mathrm{K}^{+}\right)$-ATPase and lysolecithin acyltransferase in plasma membranes of mitogen-stimulated rabbit thymocytes," The Journal of Biological Chemistry, vol. 256, no. 17, pp. 9198-9204, 1981.

[11] V. Pires, R. C. Harab, B. Olej, and V. M. Rumjanek, "Ouabain effects on activated lymphocytes: augmentation of CD25 expression on TPA-stimulated cells and of CD69 on PHA- and TPA-stimulated cells," International Journal of Immunopharmacology, vol. 19, no. 3, pp. 143-148, 1997.

[12] V. L. G. de Moraes, B. Olej, L. de La Rocque, and V. M. Rumjanek, "Lack of sensitivity to ouabain in natural killer activity," The FASEB Journal, vol. 3, no. 12, pp. 2425-2429, 1989.
[13] J. Echevarria-Lima, E. G. de Araújo, L. de Meis, and V. M. Rumjanek, " $\mathrm{Ca}^{2+}$ mobilization induced by ouabain in thymocytes involves intracellular and extracellular $\mathrm{Ca}^{2+}$ pools," Hypertension, vol. 41, no. 6, pp. 1386-1392, 2003.

[14] S. Rodrigues Mascarenhas, J. Echevarria-Lima, N. F. dos Santos, and V. M. Rumjanek, "CD69 expression induced by thapsigargin, phorbol ester and ouabain on thymocytes is dependent on external $\mathrm{Ca}^{2+}$ entry," Life Sciences, vol. 73, no. 8, pp. 1037-1051, 2003.

[15] C. L. Mann, C. D. Bortner, C. M. Jewell, and J. A. Cidlowski, "Glucocorticoid-induced plasma membrane depolarization during thymocyte apoptosis: association with cell shrinkage and degradation of the $\mathrm{Na}^{+} / \mathrm{K}^{+}$-adenosine triphosphatase," Endocrinology, vol. 142, no. 12, pp. 5059-5068, 2001.

[16] S. Rodrigues-Mascarenhas, N. F. dos Santos, and V. M. Rumjanek, "Synergistic effect between ouabain and glucocorticoids for the induction of thymic atrophy," Bioscience Reports, vol. 26, no. 2, pp. 159-169, 2006.

[17] R. C. Valente, C. R. Nascimento, E. G. Araújo, and V. M. Rumjanek, "mCD14 expression in human monocytes is downregulated by ouabain via transactivation of epithelial growth factor receptor and activation of p38 mitogenactivated protein kinase," NeuroImmunomodulation, vol. 16, no. 4, pp. 228-236, 2009.

[18] A. D. Foey, A. Crawford, and N. D. Hall, "Modulation of cytokine production by human mononuclear cells following impairment of Na,K-ATPase activity," Biochimica et Biophysica Acta, vol. 1355, no. 1, pp. 43-49, 1997.

[19] P. Kometiani, J. Li, L. Gnudi, B. B. Kahn, A. Askari, and Z. Xie, "Multiple signal transduction pathways link $\mathrm{Na}^{+} / \mathrm{K}^{+}$ATPase to growth-related genes in cardiac myocytes: the roles of Ras and mitogen-activated protein kinases," The Journal of Biological Chemistry, vol. 273, no. 24, pp. 15249-15256, 1998.

[20] M. Haas, A. Askari, and Z. Xie, "Involvement of Src and epidermal growth factor receptor in the signal-transducing function of $\mathrm{Na}^{+} / \mathrm{K}^{+}$-ATPase," The Journal of Biological Chemistry, vol. 275, no. 36, pp. 27832-27837, 2000.

[21] K. Mohammadi, P. Kometiani, Z. Xie, and A. Askari, "Role of protein kinase $C$ in the signal pathways that link $\mathrm{Na}^{+} / \mathrm{K}^{+}$ATPase to ERK1/2," The Journal of Biological Chemistry, vol. 276, no. 45, pp. 42050-42056, 2001.

[22] Z. Xie, "Ouabain interaction with cardiac Na/K-ATPase reveals that the enzyme can act as a pump and as a signal transducer," Cellular and Molecular Biology, vol. 47, no. 2, pp. 383-390, 2001.

[23] S. Harwood and M. M. Yaqoob, "Ouabain-induced cell signaling," Frontiers in Bioscience, vol. 10, 1, pp. 2011-2017, 2005.

[24] S. Rodrigues-Mascarenhas, F. F. Bloise, J. Moscat, and V. M. Rumjanek, "Ouabain inhibits p38 activation in thymocytes," Cell Biology International, vol. 32, no. 10, pp. 1323-1328, 2008.

[25] E. R. Sherwood and T. Toliver-Kinsky, "Mechanisms of the inflammatory response," Best Practice \& Research Clinical Anaesthesiology, vol. 18, no. 3, pp. 385-405, 2004.

[26] A. Matsumori, K. Ono, R. Nishio et al., "Modulation of cytokine production and protection against lethal endotoxemia by the cardiac glycoside ouabain," Circulation, vol. 96, no. 5, pp. 1501-1506, 1997.

[27] Q. Yang, W. Huang, C. Jozwik et al., "Cardiac glycosides inhibit TNF- $\alpha /$ NF- $\kappa$ B signaling by blocking recruitment of TNF receptor-associated death domain to the TNF receptor," Proceedings of the National Academy of Sciences of the United States of America, vol. 102, no. 27, pp. 9631-9636, 2005. 
[28] M. Zimmermann, "Ethical guidelines for investigations of experimental pain in conscious animals," Pain, vol. 16, no. 2, pp. 109-110, 1983.

[29] D. F. P. Leite, J. Echevarria-Lima, S. C. Ferreira, J. B. Calixto, and V. M. Rumjanek, "ABCC transporter inhibition reduces zymosan-induced peritonitis," Journal of Leukocyte Biology, vol. 82, no. 3, pp. 630-637, 2007.

[30] C. R. Correa and J. B. Calixto, "Evidence for participation of $\mathrm{B} 1$ and B2 kinin receptors in formalin-induced nociceptive response in the mouse," British Journal of Pharmacology, vol. 110, no. 1, pp. 193-198, 1993.

[31] J. C. Castardo, A. S. Prudente, J. Ferreira et al., "Antiinflammatory effects of hydroalcoholic extract and two biflavonoids from Garcinia gardneriana leaves in mouse paw oedema," Journal of Ethnopharmacology, vol. 118, no. 3, pp. 405-411, 2008.

[32] D. Rodriguez, B. S. Cavada, J. T. Abreu-de-Oliveira, R. deAzevedo-Moreira, and M. Russo, "Differences in macrophage stimulation and leukocyte accumulation in response to intraperitoneal administration of glucose/mannose-binding plant lectins," Brazilian Journal of Medical and Biological Research, vol. 25, no. 8, pp. 823-826, 1992.

[33] J. G. Cripps, F. A. Crespo, P. Romanovskis, A. F. Spatola, and R. Fernandez-Botran, "Modulation of acute inflammation by targeting glycosaminoglycan-cytokine interactions," International Immunopharmacology, vol. 5, no. 11, pp. 1622-1632, 2005.

[34] G. V. B. Cruz, P. V. S. Pereira, F. J. Patrício et al., "Increase of cellular recruitment, phagocytosis ability and nitric oxide production induced by hydroalcoholic extract from Chenopodium ambrosioides leaves," Journal of Ethnopharmacology, vol. 111, no. 1, pp. 148-154, 2007.

[35] R. Koster, M. Anderson, and E. J. Debber, "Acetic acid for analgesic screening," Federation Proceedings, vol. 18, pp. 412414, 1959.

[36] G. Woolfe and A. D. MacDonald, "The evaluation of the analgesic action of pethidine hydrochloride (demerol)," Journal of Pharmacology and Experimental Therapeutics, vol. 80, pp. 300307, 1944.

[37] F. D. S. Oliveira, D. P. De Sousa, and R. N. de Almeida, "Antinociceptive effect of hydroxydihydrocarvone," Biological \& Pharmaceutical Bulletin, vol. 31, no. 4, pp. 588-591, 2008.

[38] R. G. Lister, "The use of a plus-maze to measure anxiety in the mouse," Psychopharmacology, vol. 92, no. 2, pp. 180-185, 1987.

[39] S. Cuzzocrea, B. Zingarelli, G. Calapai, F. Nava, and A. P. Caputi, "Zymosan-activated plasma induces paw oedema by nitric oxide and prostaglandin production," Life Sciences, vol. 60, no. 3, pp. 215-220, 1997.

[40] R. Vinegar, J. F. Truax, J. L. Selph, P. R. Johnston, A. L. Venable, and K. K. McKenzie, "Pathway to carrageenan-in-duced inflammation in the hind limb of the rat," Federation Proceedings, vol. 46, no. 1, pp. 118-126, 1987.

[41] R. L. C. Handy and P. K. Moore, "A comparison of the effects of L-NAME, 7-NI and L-NIL on caurageenan-induced hindpaw oedema and NOS activity," British Journal of Pharmacology, vol. 123, no. 6, pp. 1119-1126, 1998.

[42] L. Pillemer, L. Blum, I. H. Lepow et al., “The properdin system and immunity: I. Demonstration and isolation of a new serum protein, properdin, and its role in immune phenomena," Science, vol. 120, no. 3112, pp. 279-285, 1954.

[43] J. Lago, A. Alfonso, M. R. Vieytes, and L. M. Botana, "Ouabain-induced enhancement of rat mast cells response.
Modulation by protein phosphorylation and intracellular $\mathrm{pH}$," Cellular Signalling, vol. 13, no. 7, pp. 515-524, 2001.

[44] T. Okazaki, V. S. Ilea, A. Okazaki, K. Wicher, R. E. Reisman, and C. E. Arbesman, "Inhibition of antigen induced histamine release by ouabain," Journal of Allergy and Clinical Immunology, vol. 57, no. 5, pp. 454-462, 1976.

[45] M. Senol, I. H. Ozerol, A. V. Patel, and D. P. Skoner, "The effect of $\mathrm{Na}^{+}-\mathrm{K}^{+}$ATPase inhibition by ouabain on histamine release from human cutaneous mast cells," Molecular and Cellular Biochemistry, vol. 294, no. 1-2, pp. 25-29, 2007.

[46] M. G. Henriques, P. M. Silva, M. A. Martins et al., "Mouse paw edema. A new model for inflammation?" Brazilian Journal of Medical and Biological Research, vol. 20, no. 2, pp. 243-249, 1987.

[47] A. Ianaro, C. A. O’Donnell, M. Di Rosa, and F. Y. Liew, "A nitric oxide synthase inhibitor reduces inflammation, downregulates inflammatory cytokines and enhances interleukin10 production in carrageenin-induced oedema in mice," Immunology, vol. 82, no. 3, pp. 370-375, 1994.

[48] A. R. S. Brito and M. A. Antonio, "Oral anti-inflammatory and anti-ulcerogenic activities of a hydroalcoholic extract and partitioned fractions of Turnera ulmifolia (Turneraceae)," Journal of Ethnopharmacology, vol. 61, no. 3, pp. 215-228, 1998.

[49] J. G. Cripps, F. A. Crespo, P. Romanovskis, A. F. Spatola, and R. Fernández-Botrán, "Modulation of acute inflammation by targeting glycosaminoglycan-cytokine interactions," International Immunopharmacology, vol. 5, no. 11, pp. 1622-1632, 2005.

[50] M. Burian and G. Geisslinger, "COX-dependent mechanisms involved in the antinociceptive action of NSAIDs at central and peripheral sites," Pharmacology \& Therapeutics, vol. 107, no. 2, pp. 139-154, 2005.

[51] A. Dray, "Inflammatory mediators of pain," British Journal of Anaesthesia, vol. 75, no. 2, pp. 125-131, 1995.

[52] J. D. Richardson and M. R. Vasko, "Cellular mechanisms of neurogenic inflammation," The Journal of Pharmacology and Experimental Therapeutics, vol. 302, no. 3, pp. 839-845, 2002.

[53] H. Vanegas and H.-G. Schaible, "Prostaglandins and cycloxygenases in the spinal cord," Progress in Neurobiology, vol. 64, no. 4, pp. 327-363, 2001.

[54] E. M. Franzotti, C. V. F. Santos, H. M. S. Rodrigues, R. H. V. Mourão, M. R. Andrade, and A. R. Antoniolli, "Antiinflammatory, analgesic activity and acute toxicity of Sida cordifolia L. (Malva-branca)," Journal of Ethnopharmacology, vol. 72, no. 1-2, pp. 273-278, 2000.

[55] R. Deraedt, S. Jouquey, F. Delevallee, and M. Flahaut, "Release of prostaglandins $\mathrm{E}$ and $\mathrm{F}$ in an algogenic reaction and its inhibition," European Journal of Pharmacology, vol. 61, no. 1, pp. 17-24, 1980.

[56] H. O. Collier, L. C. Dinneen, C. A. Johnson, and C. Schneider, "The abdominal constriction response and its suppression by analgesic drugs in the mouse," British Journal of Pharmacology and Chemotherapy, vol. 32, no. 2, pp. 295-310, 1968.

[57] R. C. da Silveira e Sá, L. E. G. de Oliveira, F. F. Nóbrega, J. Bhattacharyya, and R. N. de Almeida, "Antinociceptive and toxicological effects of Dioclea grandiflora seed pod in mice," Journal of Biomedicine and Biotechnology, vol. 2010, Article ID 606748, 6 pages, 2010.

[58] D. S. França, A. L. Souza, K. R. Almeida, S. S. Dolabella, C. Martinelli, and M. M. Coelho, "B vitamins induce an antinociceptive effect in the acetic acid and formaldehyde models of nociception in mice," European Journal of Pharmacology, vol. 421, no. 3, pp. 157-164, 2001. 
[59] A. R. Campos, F. A. A. Albuquerque, V. S. N. Rao, M. A. M. Maciel, and A. C. Pinto, "Investigations on the antinociceptive activity of crude extracts from Croton cajucara leaves in mice," Fitoterapia, vol. 73, no. 2, pp. 116-120, 2002.

[60] W. Zeng, S. Dohi, H. Shimonaka, and T. Asano, "Spinal antinociceptive action of $\mathrm{Na}^{+}-\mathrm{K}^{+}$pump inhibitor ouabain and its interaction with morphine and lidocaine in rats," Anesthesiology, vol. 90, no. 2, pp. 500-508, 1999.

[61] W. Zeng, X. Chen, and S. Dohi, "Antinociceptive synergistic interaction between clonidine and ouabain on thermal nociceptive tests in the rat," The Journal of Pain, vol. 8, no. 12, pp. 983-988, 2007.

[62] J. Borsy, E. Csanyi, and I. Lazar, "A method of assaying tranquilizing drugs based on the inhibition of orientational hypermotility," Archives Internationales de Pharmacodynamie et de Thérapie, vol. 124, pp. 180-190, 1960.

[63] S. Pellow, P. Chopin, S. E. File, and M. Briley, "Validation of open:closed arm entries in an elevated plus-maze as a measure of anxiety in the rat," Journal of Neuroscience Methods, vol. 14, no. 3, pp. 149-167, 1985.

[64] R. J. Rodgers and N. J. T. Johnson, "Factor analysis of spatiotemporal and ethological measures in the murine elevated plus-maze test of anxiety," Pharmacology Biochemistry \& Behavior, vol. 52, no. 2, pp. 297-303, 1995.

[65] D. Treit, J. Menard, and C. Royan, "Anxiogenic stimuli in the elevated plus-maze," Pharmacology Biochemistry \& Behavior, vol. 44, no. 2, pp. 463-469, 1993.

[66] K. C. Montgomery, "The relation between fear induced by novel stimulation and exploratory behavior," Journal of Comparative \& Physiological Psychology, vol. 48, no. 4, pp. 254-260, 1955. 


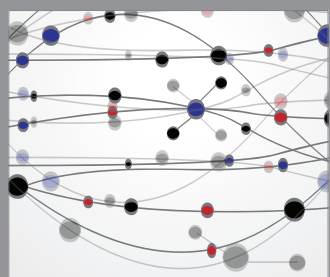

The Scientific World Journal
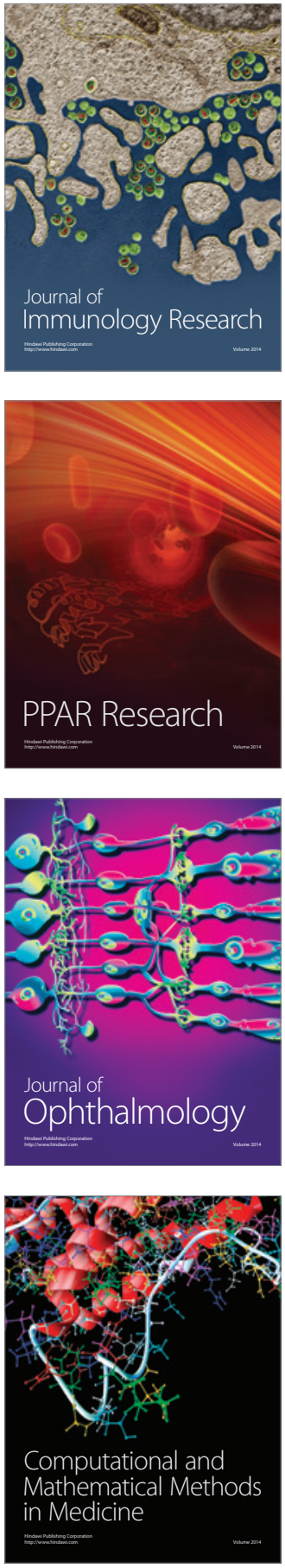

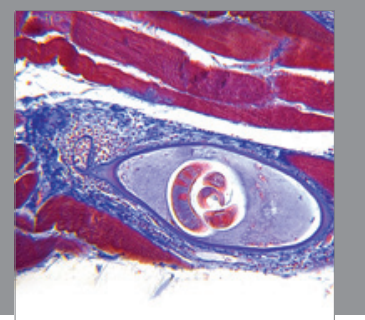

Gastroenterology

Research and Practice
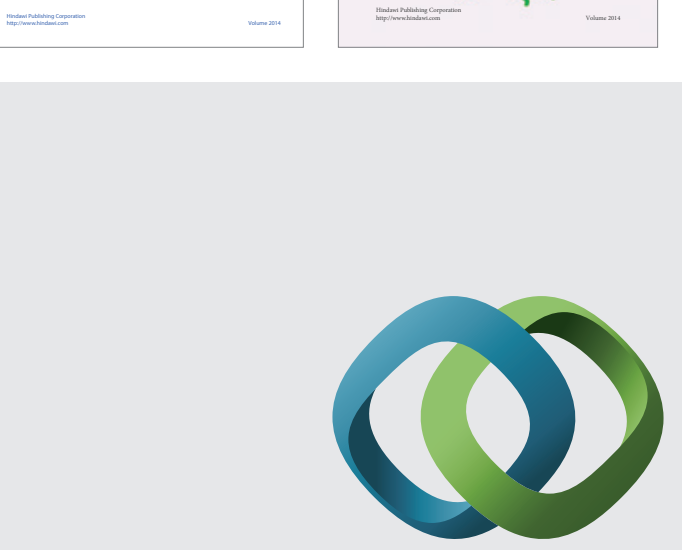

\section{Hindawi}

Submit your manuscripts at

http://www.hindawi.com
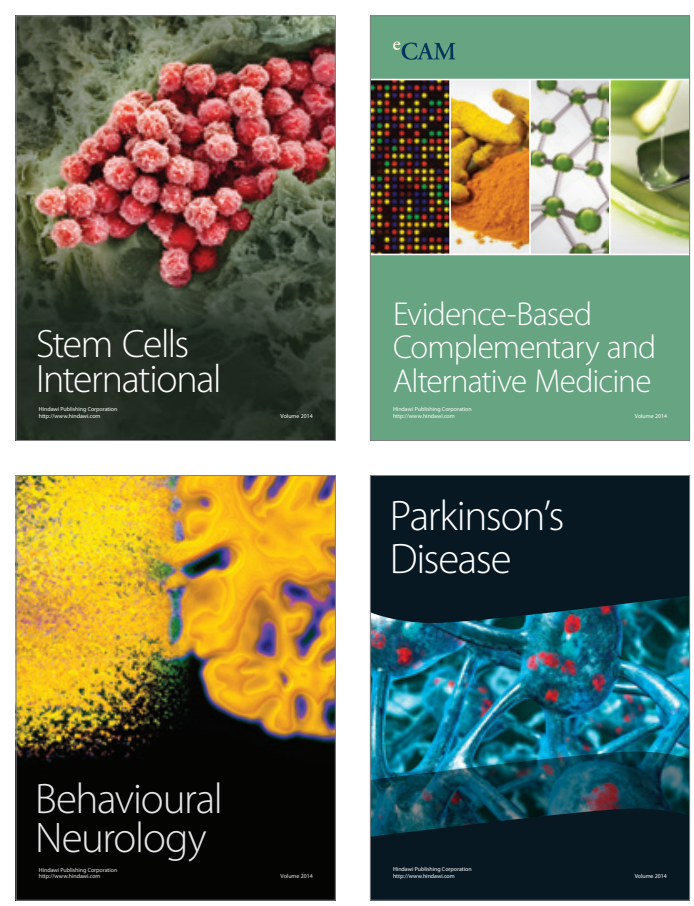

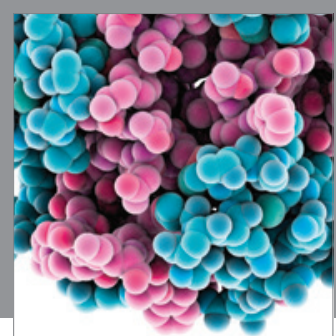

Journal of
Diabetes Research

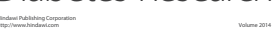

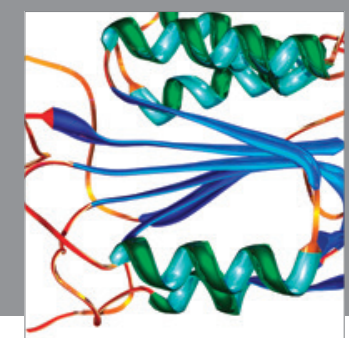

Disease Markers
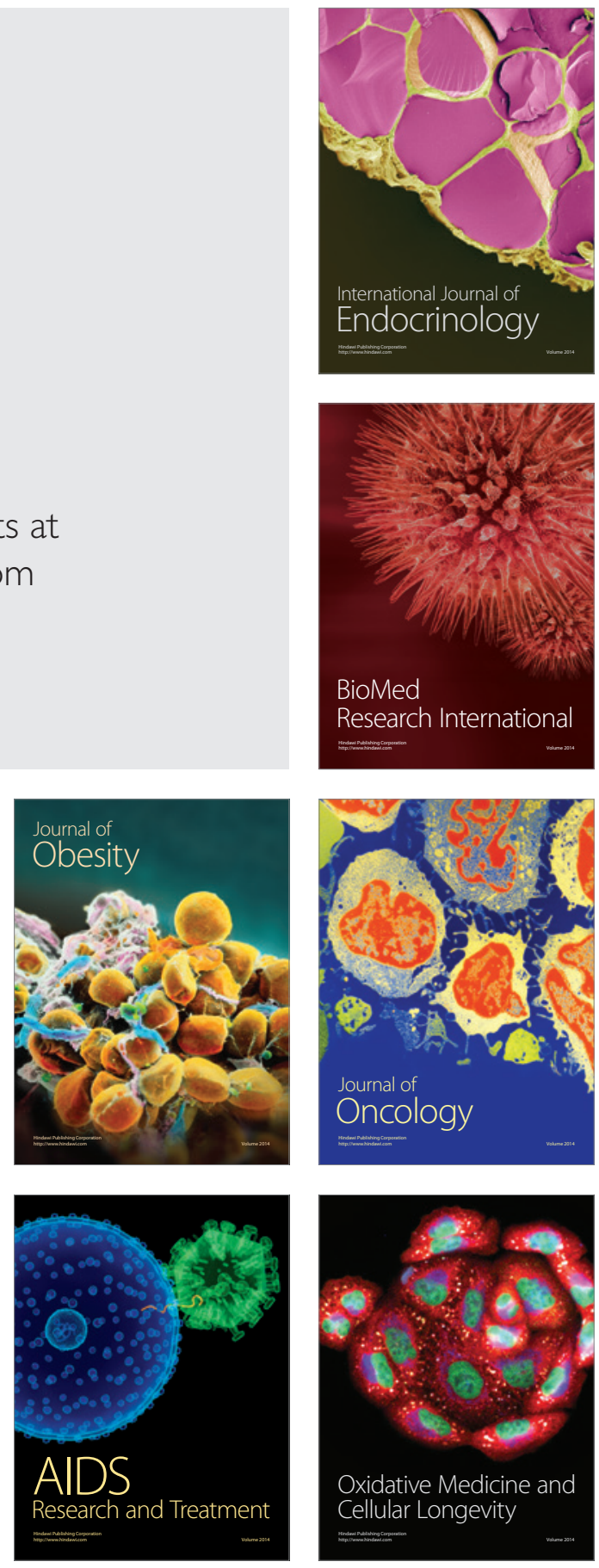